\title{
THE EFFECT OF THE BACTERIUM BACILLUS MEGATERIUM VAR. PHOSPHATICUM, THE AMINO ACID L-ALPHA PROLINE AND MINERAL FERTILISATION WITH NITROGEN ON HEAVY METAL CONTENT IN SPRING WHEAT (TRITICUM AESTIVUM L.) GRAIN
}

\author{
PŁAZA, A.* - RZĄŻEWSKA, E. \\ Siedlce University of Natural Sciences and Humanities, Faculty of Agrobioengineering and \\ Animal Husbandry, Siedlce, Poland \\ *Corresponding author \\ e-mail: anna.plaza@uph.edu.pl
}

(Received 21 $1^{\text {st }}$ Jun 2021; accepted $3^{\text {rd }}$ Sep 2021)

\begin{abstract}
The objective of the present work was to determine the effect of the bacterium Bacillus megaterium var. phosphaticum, the amino acid L-alpha proline and mineral fertilisation with nitrogen on heavy metal content in spring wheat (Triticum aestivum L.) grain destined for human consumption. Field research was conducted on a family-owned farm located in Krzymosze, Poland. Two factors were examined: factor I - biological products: control where no biological products were applied, Bacillus megaterium var. phosphaticum, L-alpha proline, Bacillus megaterium var. phosphaticum + L-alpha proline; factor II - mineral fertilisation with nitrogen: unfertilised control, $60 \mathrm{~kg} \mathrm{Noha}^{-1}, 90 \mathrm{~kg} \mathrm{Nha}^{-1}$, and $120 \mathrm{~kg} \mathrm{Nha}^{-1}$. Grain samples were taken to determine $\mathrm{Cu}, \mathrm{Zn}, \mathrm{Cd}, \mathrm{Cr}$ and $\mathrm{Ni}$ contents. The research demonstrated that weather conditions during the growing season had a significant influence on the heavy metal content of spring wheat grains. Increasing rates of mineral fertilisation with nitrogen contributed to an increase in the spring wheat grain content of heavy metals, an exception being zinc content in the grain of spring wheat fertilised with $120 \mathrm{~kg} \mathrm{Nh}^{-1}$. The lowest heavy metal content was recorded in the grain of spring wheat treated with the bacteria Bacillus megaterium var. phosphaticum + the amino acid L-alpha proline, regardless of whether the crop was unfertilised or fertilised with the rates of 60 and $90 \mathrm{~kg} \mathrm{~N}^{-1}$. Keywords: phosphorus bacteria, mineral fertilisation, biostimulator, content in grain metal
\end{abstract}

\section{Introduction}

Spring wheat grain is a raw material for the food industry so its content of heavy metals should be as low as possible. Some of these metals, e.g. Ni, $\mathrm{Cu}$ and $\mathrm{Zn}$, are microelements necessary for biomolecules, and to maintain cell structure, function and proliferation (Khajeh et al., 2010). The metals are potentially toxic if present in excess in food. They may be the cause of genetic disorders (Zheng et al., 2008). Other metals, e.g. Cd, Pb and $\mathrm{Cr}$ are carcinogenic substances and they are responsible for the occurrence of conditions such as Alzheimer's disease, Parkinson's disease, multiple sclerosis and osteoporosis. Also, they negatively affect such organs as the heart, kidneys and lungs as well as the immune system (Jamova and Valko, 2011; Zakir et al., 2011; Pirsaheb et al., 2015). Numerous research have revealed excessive amounts of heavy metals in cereals and rice grown in various countries. This is due to the fact that currently harmful substances in the environment are pesticide residues and heavy metal compounds. Reducing the emission of heavy metal compounds is more difficult to achieve. Their main sources are the steel industry, energy, mining and transport. That is why it is of paramount importance to constantly monitor and check cereal grain for heavy metals. The value of guidance documents and safety standards as established by Food Safety Authorities (Table 2) around the world cannot be overstated in terms of protecting public health and providing 
guidance and assistance to stakeholders, not least farmers and processors (Thielecke and Nugent, 2018). Refining grains will reduce the presence of many contaminants but it also removes 50 to $80 \%$ of phytonutrients from whole grains. The studies demonstrated that it is these phytonutrients, (vitamins, minerals and fibres) that may exert a potentially protective effect against toxic metals in particular (Thielecke and Nugent, 2018). Further, the consumer also has a choice in mitigating any risk from contaminants, and to do so best by continuing to eat a healthy balanced diet, rich in nutrient dense foods, and including whole grain foods (Thielecke and Nugent, 2018).

According to Shicheng et al. (2018), mineral fertilisation with nitrogen increases the wheat grain content of heavy metals. Jastrzębska and Kostrzewska (2019) have demonstrated that an application of the phosphorus-dissolving bacteria Bacillus megaterium, compared to mineral fertilisation of spring wheat, contributed to a decline in the soil content of heavy metals. In the research, the phosphorus-dissolving bacteria were applied with fertiliser as ash produced from sewage sludge, and they reduced heavy metal content in the soil as opposed to mineral fertilisation. Also Asfa et al. (2020) observed lower phytotoxicity of heavy metals after inclusion of microbiology in wheat cultivation. Apart from microorganisms, modern agriculture also recommends an application of biostimulants, including amino acids (Calvo et al., 2014). Biostimulants serve to control and enhance plant life processes, and thus they increase plant resistance to stress and stimulate the development of rooting (Du Jardin, 2015). In this respect, it is a novel approach to apply the bacteria Bacillus megaterium var. phosphaticum and the amino acid L-alpha proline which willhopefully contribute to a decline in heavy metal content in spring wheat grain. As there is no research into this issue, it was attempted to determine the impact of the bacteria Bacillus megaterium var. phosphaticum, the amino acid L-alpha proline and mineral fertilisation with nitrogen on heavy metal content in the grain of spring wheat destined for human consumption.

\section{Materials and Methods}

A field experiment was conducted on a family-owned farm in Krzymosze near Siedlce, Poland, in 2017-2019. The trial was set up on soil classified as Stagnic Luvisol and whose contents of available macroelements was as follows: $\mathrm{P} 8.2, \mathrm{~K} 18.7$, and $\mathrm{Mg} 4.8$

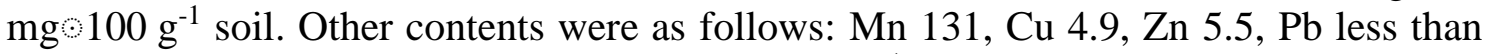
16.2, Cd 0.14, Cr less than 12.3 and $\mathrm{Ni} 12.4 \mathrm{mg} \mathrm{kg}^{-1}$ soil. Soil reaction was neutral and humus content was $1.88 \%$. The experiment was a split-block arrangement with three replicates. The experimental factors were as follows: factor I - biological products: control where no biological products were applied, Bacillus megaterium var. phosphaticum $1 \mathrm{lha}^{-1}$, L-alpha proline $2 \mathrm{~g} \mathrm{ha}^{-1}$, Bacillus megaterium var. phosphaticum $1 \mathrm{lha}^{-1}+\mathrm{L}$-alpha proline $2 \mathrm{~g} \mathrm{ha}^{-1}$; factor II - mineral fertilisation with nitrogen: unfertilised control, $60 \mathrm{~kg} \mathrm{~N}^{-1}$ (pre-plant), $90 \mathrm{~kg} \mathrm{~N}^{-1}\left(60 \mathrm{~kg} \mathrm{~N}^{-1} \mathrm{ha}^{-1}\right.$ preplant $+30 \mathrm{~kg} \mathrm{~N}^{-1}$ at the stem elongation stage), and $120 \mathrm{~kg} \mathrm{~N}^{-1} \mathrm{ha}^{-1}\left(60 \mathrm{~kg} \mathrm{~N}^{-1} \mathrm{pre}^{-}\right.$ plant $+30 \mathrm{~kg} \mathrm{~N}^{-1}$ at the stem elongation stage $+30 \mathrm{~kg} \mathrm{~N}^{-1}$ as foliar application of $8 \%$ solution of urea at the early ear formation stage).

Spring wheat cv. Mandaryna was grown after maize. Phosphorus and potassium fertiliser rates were adjusted to soil contents of available forms of these elements and were as follows: P $30.8 \mathrm{~kg}^{-1}$ and $\mathrm{K} 99.6 \mathrm{~kg}^{-1}$. Mineral fertilisation with nitrogen was applied as described for factor II above. Spring wheat was sown in early April at the amount of 500 grains per $1 \mathrm{~m}^{2}$. Biological products were applied once at the stage of 
spring wheat tillering. Spring wheat was harvested in early August. From each plot after the grain was harvested, a representative sample with a volume of $250 \mathrm{~g}$ was taken. Then it was ground and intended for chemical analysis. During harvest, grain samples were taken in each plot to determine microelements. $\mathrm{Cu}, \mathrm{Zn}, \mathrm{Mn}, \mathrm{Pb}, \mathrm{Cd}, \mathrm{Cr}$ and $\mathrm{Ni}$ contents were determined by means of inductively coupled plasma optical emission spectrometry (ICP-OES) using an emission spectrometer Perkin Elmer Optima 8300.

The results for each trait tested were subjected to ANOVA suitable for the split-block design. When significant sources of variation were confirmed, their means were separated using Tukey test. Calculations were performed in MS Excel 12.0. The results for each characteristic were subjected to analysis of variance following the mathematical model: $\mathrm{y}_{\mathrm{ijl}}=\mathrm{n}+\mathrm{a}_{\mathrm{i}}+\mathrm{g}_{\mathrm{i}}+\mathrm{e}_{\mathrm{ij}}{ }^{(1)}+\mathrm{b}_{1}+\mathrm{e}_{\mathrm{jl}}{ }^{(2)}+\mathrm{ab}_{\mathrm{il}}+\mathrm{e}_{\mathrm{ijl}}{ }^{(3)}$, where $\mathrm{a}=1 . .4 ; \mathrm{b}=1,2, \ldots 4 ; \mathrm{n}=1,2,3$ (number of replicates); $y_{i j l}-$ value of the examined characteristic; $a_{i}-$ effect of $i$-th level of factor $\mathrm{A} ; \mathrm{g}_{\mathrm{j}}$ - effect of replicates (blocks); $\mathrm{e}_{\mathrm{ij}}{ }^{(1)}$ - error 1 resulting from the interaction: factor $A \times$ replicates; $b_{1}-$ effect of 1 -th level of factor $B$; $e_{j l}{ }^{(2)}$ - error 2 from the interaction: factor $\mathrm{B} \times$ replicates; $a b_{i l}-$ effect of the interaction: factor $\mathrm{A} \times$ factor $\mathrm{B}$; $\mathrm{e}_{\mathrm{ijl}}{ }^{(3)}-$ random error. The course of weather conditions in the years of the research was varied (Table 1).

Table 1. Weather conditions in the growing season of spring wheat according to the Zawady Meteorological Station

\begin{tabular}{|c|c|c|c|c|c|c|}
\hline \multirow{2}{*}{ Years } & \multicolumn{5}{|c|}{ Month } & \multirow{2}{*}{ Mean } \\
\hline & IV & $\mathbf{V}$ & VI & VII & VIII & \\
\hline \multicolumn{7}{|c|}{ Mean air temperature ${ }^{\circ} \mathrm{C}$} \\
\hline 2017 & 6.9 & 13.9 & 17.8 & 16.9 & 18.4 & 14.8 \\
\hline 2018 & 13.1 & 17.0 & 18.3 & 20.4 & 20.6 & 17.9 \\
\hline 2019 & 9.8 & 13.3 & 17.9 & 18.5 & 19.9 & 15.9 \\
\hline Long-term $(50 \mathrm{yr})$ mean & 8.2 & 14.2 & 17.6 & 19.7 & 19.1 & 15.8 \\
\hline \multicolumn{7}{|c|}{ Rainfall sum, mm } \\
\hline 2017 & 59.6 & 49.5 & 57.9 & 23.6 & 54.7 & 245.3 \\
\hline 2018 & 34.5 & 27.3 & 31.5 & 67.1 & 24.5 & 184.9 \\
\hline 2019 & 5.9 & 59.8 & 35.9 & 29.7 & 43.9 & 175.2 \\
\hline Long-term (50yr) mean & 37.4 & 47.1 & 48.1 & 65.5 & 43.5 & 241.6 \\
\hline
\end{tabular}

The most favorable year for the cultivation of spring wheat was 2017, when the highest amount of rainfall was recorded. Worse weather conditions were recorded in 2018, with a lower total of precipitation and an average air temperature higher than the long-term average. The strongest rainfall shortage was recorded in 2019. The average air temperature oscillated around the long-term average.

Table 2 shows the regulatory autorities' permissible metal limits WHO/FAO.

Table 2. Metal levels in food by WHO/FAO

\begin{tabular}{c|c}
\hline Metal & Concentrations $(\boldsymbol{\mu g} / \mathbf{g})$ \\
\hline $\mathrm{Cd}$ & 0.10 \\
$\mathrm{Cu}$ & 73.00 \\
$\mathrm{Cr}$ & 2.30 \\
$\mathrm{~Pb}$ & 0.30 \\
$\mathrm{Zn}$ & 100.00 \\
\hline
\end{tabular}




\section{Results and Discussion}

Heavy metal contents in spring wheat grain were significantly affected by weather conditions and their interaction with biological products (Table 3).

Table 3. Spring wheat grain content of heavy metals according to biological products applied in 2017-2019, $\mathrm{mg} \mathrm{kg}^{-1} \mathrm{DM}$

\begin{tabular}{|c|c|c|c|}
\hline \multirow{2}{*}{ Biological products (A) } & \multicolumn{3}{|c|}{ Years $(\mathbf{Y})$} \\
\hline & 2017 & 2018 & 2019 \\
\hline \multicolumn{4}{|c|}{ Manganese } \\
\hline Control & $82.14 \mathrm{c}$ & $79.49 \mathrm{~d}$ & $77.68 \mathrm{~d}$ \\
\hline Bacillus megaterium var. phosphaticum & $72.32 \mathrm{a}$ & $72.69 \mathrm{~b}$ & $71.07 \mathrm{~b}$ \\
\hline L-alpha proline & $78.98 \mathrm{~b}$ & $76.34 \mathrm{c}$ & $74.72 \mathrm{c}$ \\
\hline $\begin{array}{c}\text { Bacillus megaterium var. phosphaticum } \\
+ \text { L-alpha proline }\end{array}$ & $71.14 \mathrm{a}$ & $68.51 \mathrm{a}$ & $66.89 \mathrm{~d}$ \\
\hline Means & $76.15 \mathrm{C}$ & $74.26 \mathrm{~B}$ & $72.59 \mathrm{~A}$ \\
\hline \multicolumn{4}{|c|}{ Zinc } \\
\hline Control & $18.59 \mathrm{a}$ & $20.00 \mathrm{a}$ & $20.65 a$ \\
\hline Bacillus megaterium var. phosphaticum & $23.16 \mathrm{c}$ & $24.57 \mathrm{c}$ & $25.22 \mathrm{c}$ \\
\hline L-alpha proline & $21.59 \mathrm{~b}$ & $23.05 b$ & $23.71 b$ \\
\hline $\begin{array}{c}\text { Bacillus megaterium var. phosphaticum } \\
\text { + L-alpha proline }\end{array}$ & $25.68 \mathrm{~d}$ & $27.08 \mathrm{~d}$ & $27.72 d$ \\
\hline Means & $22.26 \mathrm{~A}$ & $23.68 \mathrm{~B}$ & $24.33 \mathrm{C}$ \\
\hline \multicolumn{4}{|c|}{ Copper } \\
\hline Control & $6.24 \mathrm{c}$ & $5.37 \mathrm{~b}$ & $5.01 \mathrm{~b}$ \\
\hline Bacillus megaterium var. phosphaticum & $5.30 \mathrm{a}$ & $4.43 \mathrm{a}$ & $4.07 \mathrm{a}$ \\
\hline L-alpha proline & $5.49 \mathrm{ab}$ & $4.62 \mathrm{a}$ & $4.26 \mathrm{a}$ \\
\hline $\begin{array}{l}\text { Bacillus megaterium var. phosphaticum } \\
+ \text { L-alpha proline }\end{array}$ & $5.08 \mathrm{a}$ & $4.23 \mathrm{a}$ & $3.87 \mathrm{a}$ \\
\hline Means & $5.53 \mathrm{C}$ & $4.66 \mathrm{~B}$ & $4.30 \mathrm{~A}$ \\
\hline \multicolumn{4}{|c|}{ Nickel } \\
\hline Control & $0.769 \mathrm{c}$ & $0.669 \mathrm{c}$ & $0.638 \mathrm{a}$ \\
\hline Bacillus megaterium var. phosphaticum & $0.638 \mathrm{~b}$ & $0.538 \mathrm{~b}$ & $0.508 \mathrm{~b}$ \\
\hline L-alpha proline & $0.671 \mathrm{~b}$ & $0.573 b$ & $0.543 b$ \\
\hline $\begin{array}{l}\text { Bacillus megaterium var. phosphaticum } \\
\text { + L-alpha proline }\end{array}$ & $0.556 \mathrm{a}$ & $0.458 \mathrm{a}$ & $0.427 \mathrm{a}$ \\
\hline Means & $0.659 \mathrm{~B}$ & $0.560 \mathrm{~A}$ & $0.529 \mathrm{~A}$ \\
\hline \multicolumn{4}{|c|}{ Chromium } \\
\hline Control & $0.463 \mathrm{c}$ & $0.378 \mathrm{~d}$ & $0.355 \mathrm{c}$ \\
\hline Bacillus megaterium var. phosphaticum & $0.310 \mathrm{a}$ & $0.225 b$ & $0.203 \mathrm{a}$ \\
\hline L-alpha proline & $0.355 \mathrm{~b}$ & $0.271 \mathrm{c}$ & $0.248 b$ \\
\hline $\begin{array}{l}\text { Bacillus megaterium var. phosphaticum } \\
+ \text { L-alpha proline }\end{array}$ & $0.319 \mathrm{a}$ & $0.189 \mathrm{a}$ & $0.181 \mathrm{a}$ \\
\hline Means & $0.362 \mathrm{~B}$ & $0.266 \mathrm{~A}$ & $0.247 \mathrm{~A}$ \\
\hline
\end{tabular}

In 2017, characterised by the highest precipitation sum, there was recorded an increase in manganese, copper, nickel and chromium contents as well as a decline in zinc content in spring wheat grain compared with the dry years 2018 and 2019 whose precipitation 
sums were much lower. Similarly, Radkowski et al. (2020a) reported a decline in microelements in the year with a higher precipitation sum compared with dry years. In the present study, an interaction was confirmed. The lowest manganese, copper, nickel and chromium contents and the highest zinc content were recorded in spring wheat grain in 2018-2019, when precipitation was lower, in the plot treated with the bacteria Bacillus megaterium var. phosphaticum + the amino acid L-alpha proline. By contrast, the highest heavy metal contents, excluding zinc, were found in the control plot, where no biological products had been applied, in 2017 characterised by the highest precipitation sum.

Statistical analysis demonstrated a significant influence of the experimental factors and their interaction on manganese content in spring wheat grain (Table 4).

Table 4. Manganese content in spring wheat grain (means across 2017-2019), $\mathrm{mg}^{\circ g^{-1}} \mathrm{DM}$

\begin{tabular}{c|c|c|c|c|c}
\hline \multirow{2}{*}{ Biological products (A) } & \multicolumn{4}{|c|}{ Mineral fertilisation with nitrogen, $\mathbf{k g ~ N}^{-\mathbf{1}} \mathbf{( B )}$} & \multirow{2}{*}{ Means } \\
\cline { 2 - 5 } & Control & $\mathbf{6 0}$ & $\mathbf{9 0}$ & $\mathbf{1 2 0}$ & \\
\hline Control & $76.08 \mathrm{~d}$ & $78.50 \mathrm{~d}$ & $80.77 \mathrm{~d}$ & $83.24 \mathrm{~d}$ & $79.65 \mathrm{D}$ \\
Bacillus megaterium var. & $71.32 \mathrm{~b}$ & $72.59 \mathrm{~b}$ & $73.86 \mathrm{~b}$ & $74.33 \mathrm{~b}$ & $73.03 \mathrm{~B}$ \\
$\begin{array}{c}\text { phosphaticum } \\
\text { L-alpha proline }\end{array}$ & $74.47 \mathrm{c}$ & $75.74 \mathrm{c}$ & $77.01 \mathrm{c}$ & $79.48 \mathrm{c}$ & $76.68 \mathrm{C}$ \\
$\begin{array}{c}\text { Bacillus megaterium var. } \\
\text { phosphaticum + L-alpha proline }\end{array}$ & $66.14 \mathrm{a}$ & $68.41 \mathrm{a}$ & $69.68 \mathrm{a}$ & $71.15 \mathrm{a}$ & $68.85 \mathrm{~A}$ \\
\hline Means & $72.00 \mathrm{~A}$ & $73.81 \mathrm{~B}$ & $75.33 \mathrm{C}$ & $77.05 \mathrm{D}$ & - \\
\hline
\end{tabular}

Compared to control, biological products contributed to a decline in the spring wheat content of manganese. Also the study by Arhar and Ahmad (2018) showed that nitrogenfixing bacteria reduced Mn uptake by wheat plants. In the present study, the lowest concentration of $\mathrm{Mn}$ was recorded in spring wheat grain following an application of the bacteria Bacillus megaterium var. phosphaticumand the amino acid L-alpha proline. Kandii et al. (2016) reported a decline in Mn content in wheat after amino acids had been applied in combination with mineral fertilisation with nitrogen. The same relationship was observed by Radkowski et al. (2020). In the present study, mineral fertilisation with nitrogen significantly influenced manganese content in spring wheat grain. Increasing rates of mineral nitrogen fertiliser contributed to a significant increase in Mn content in spring wheat grain. This finding corresponds with results reported by Hellal et al. (2012) and Radkowski et al. (2020a,b). In the experiment discussed here, an interaction was confirmed indicating that the lowest manganese content was found in the grain of spring wheat grown in plots treated with the bacteria Bacillus megaterium var. phosphaticumand the amino acid L-alpha proline and not fertilised with mineral nitrogen. By contrast, the highest values were found in units fertilised with $120 \mathrm{~kg} \mathrm{~N}^{-1}$ and untreated with biological products. However, also in this case the spring wheat grain content of Mn was lower than the standards quoted by WHO/FAO, and was safe for humans (Adefarati et al., 2017).

Zinc content in spring wheat grain was significantly affected by the experimental factors and their interaction (Table 5).

Biological products significantly increased zinc content in spring wheat grain compared with control where no biological products were applied. Zinc plays an important role in plant metabolism. Both zinc excess and shortage considerably limit plant growth and development (Ociepa-Kubicka and Ociepa, 2012). It should be 
mentioned that plants growing in a polluted environment may accumulate high concentrations of this microelement, which poses a serious threat to human health (Srinivas et al., 2002; Sharma et al., 2004; Luo et al., 2013). Research by Fytianos et al. (2001), Demirezen and Ahmet (2006), Muchuweti et al. (2006) as well as Mahamed et al. (2012) demonstrated a low zinc content in cereal grain. In the present study, the highest concentration of zinc was recorded in spring wheat grain following an application of the bacteria Bacillus megaterium var. phosphaticumand the amino acid L-alpha proline. Also Athar and Ahmad (2018) reported increased zinc contents in cereal grain due to an application of bacteria. Radkowski et al. (2020a) demonstrated that an application of amino acids increases $\mathrm{Zn}$ concentration in spring wheat grain as well. In the experiment reported here, mineral fertilisation with nitrogen increased $\mathrm{Zn}$ content in spring wheat grain up to the rate $90 \mathrm{~kg} \mathrm{~N}^{-1}$. The highest rate, that is $120 \mathrm{~kg} \mathrm{~N}^{-1}$, was followed by a significant decline in the spring wheat grain content of zinc. The same relationship was demonstrated in research by Kandii et al. (2016) and Radkowski et al. (2020a,b). In the present work, an interaction was confirmed indicating that the highest zinc content was present in spring wheat grain following an application of the bacteria Bacillus megaterium var.phosphaticum, the amino acid L-alpha proline and mineral fertilisation with nitrogen at the rate of either 60 or $90 \mathrm{~kg} \mathrm{Nha}^{-1}$, it being the lowest in the control unit where no biological products had been applied, at all the rates of mineral fertilisation with nitrogen.

Table 5. Zinc content in spring wheat grain (means across 2017-2019), $\mathrm{mg} \mathrm{kg}^{-1} \mathrm{DM}$

\begin{tabular}{c|c|c|c|c|c}
\hline \multirow{2}{*}{ Biological products (A)) } & \multicolumn{4}{|c|}{ Mineral fertilisation with nitrogen, $\mathbf{~ N g ~ N a}^{-1}(\mathbf{B})$} & \multirow{2}{*}{ Means } \\
\cline { 2 - 5 } & Control & $\mathbf{6 0}$ & $\mathbf{9 0}$ & $\mathbf{1 2 0}$ & \\
\hline Control & $19.17 \mathrm{a}$ & $20.65 \mathrm{a}$ & $19.79 \mathrm{a}$ & $19.37 \mathrm{a}$ & $19.75 \mathrm{~A}$ \\
Bacillus megaterium var. & $23.05 \mathrm{~b}$ & $24.25 \mathrm{~b}$ & $26.44 \mathrm{~b}$ & $23.53 \mathrm{~b}$ & $24.32 \mathrm{C}$ \\
phosphaticum & $20.16 \mathrm{a}$ & $23.53 \mathrm{~b}$ & $24.89 \mathrm{~b}$ & $22.54 \mathrm{~b}$ & $22.78 \mathrm{~B}$ \\
$\begin{array}{c}\text { L-alpha proline } \\
\text { Bacillus megaterium var. }\end{array}$ & $25.54 \mathrm{c}$ & $26.96 \mathrm{c}$ & $28.60 \mathrm{c}$ & $26.18 \mathrm{c}$ & $26.82 \mathrm{D}$ \\
\hline phosphaticum + L-alpha proline & $21.98 \mathrm{~A}$ & $23.85 \mathrm{~B}$ & $24.93 \mathrm{C}$ & $22.91 \mathrm{~B}$ & - \\
\hline Means & & & & &
\end{tabular}

Statistical analysis demonstrated a significant impact of the experimental factors and their interaction on copper content in spring wheat grain. Biological products used in the study contributed to a significant drop in copper content in spring wheat grain compared with control. The lowest concentration of copper was recorded in spring wheat grain following an application of the bacteria Bacillus megaterium var. phosphaticumand the amino acid L-alpha proline. Research by Garcia-Fraile et al. (2015) and Vejan et al. (2016) revealed that plant growth stimulating bacteria occur around roots and are responsible for nutrient mobilisation, heavy metal sequencing and break-down of toxic elements present in soil. Also Athar and Ahmad (2018) reported that Azotobacter reduces $\mathrm{Cu}$ content in wheat grain. A similar relationship was observed by Radkowski et al. (2020a) who applied amino acids while growing wheat. In the present study, increasing rates of mineral fertilisation with nitrogen were followed by an increase in copper content in spring wheat grain. However, the content associated with the highest rate of mineral fertilisation with nitrogen, that is $120 \mathrm{~kg} \mathrm{Nha}^{-1}$, was lower than the permissible standards set by the WHO/FAO and is not harmful to humans (Adefarati et al., 2017). In studies by 
Hellal et al. (2012), Kandii et al. (2016) and Radkowski et al. (2020b), there was observed an increase in the spring wheat grain content of copper following increasing rates of mineral fertilisation with nitrogen. In the study reported here, there was confirmed an interaction which indicated that the lowest copper content was present in spring wheat grain after an application of the bacteria Bacillus megaterium var. phosphaticum, the amino acid L-alpha proline and mineral fertilisation with nitrogen at the rate of up to $90 \mathrm{~kg} \mathrm{~N} \mathrm{Nha}^{-1}$. The highest copper content was determined in control grain produced without using biological products at the highest rate of mineral fertilisation with nitrogen, that is $120 \mathrm{~kg} \mathrm{~N}^{-1}$.

Lead and cadmium contents in spring wheat grain were insignificantly affected by the experimental factors, and their concentration in spring wheat grain was too low to be detected by an emission spectrometer Perkin Elmer Optima 8300. This may be explained by the fact that the fields where the experiment was set up were located relatively far away from communication routes. Hence, spring wheat grain met standards the set by the WHO/FAO for lead and cadmium contents. Despite the low $\mathrm{Cd}$ and $\mathrm{Pb}$ contents in spring wheat grain, they must be constantly monitored and checked.

Statistical analysis demonstrated a significant influence of the experimental factors and their interaction on nickel content in spring wheat grain (Table 6).

Table 6. Nickel content in spring wheat grain (means across 2017-2019), $\mathrm{mg} \mathrm{kg}^{-1} \mathrm{DM}$

\begin{tabular}{c|c|c|c|c|c}
\hline \multirow{2}{*}{ Biological products (A) } & \multicolumn{2}{|c|}{ Mineral fertilisation with nitrogen, kg Noha $\mathbf{~}(\mathbf{B})$} & \multirow{2}{*}{ Means } \\
\cline { 2 - 5 } & Control & $\mathbf{6 0}$ & $\mathbf{9 0}$ & $\mathbf{1 2 0}$ & \\
\hline Control & $0.591 \mathrm{c}$ & $0.683 \mathrm{c}$ & $0.721 \mathrm{c}$ & $0.772 \mathrm{c}$ & $0.692 \mathrm{C}$ \\
Bacillus megaterium var. & $0.493 \mathrm{a}$ & $0.534 \mathrm{~b}$ & $0.575 \mathrm{~b}$ & $0.644 \mathrm{~b}$ & $0.562 \mathrm{~B}$ \\
$\begin{array}{c}\text { phosphaticum } \\
\text { L-alpha proline }\end{array}$ & $0.512 \mathrm{~b}$ & $0.576 \mathrm{~b}$ & $0.613 \mathrm{~b}$ & $0.681 \mathrm{~b}$ & $0.596 \mathrm{~B}$ \\
$\begin{array}{c}\text { Bacillus megaterium var. } \\
\text { phosphaticum + L-alpha proline }\end{array}$ & $0.427 \mathrm{a}$ & $0.453 \mathrm{a}$ & $0.494 \mathrm{a}$ & $0.547 \mathrm{a}$ & $0.480 \mathrm{~A}$ \\
\hline Means & $0.506 \mathrm{~A}$ & $0.562 \mathrm{~A}$ & $0.601 \mathrm{~B}$ & $0.661 \mathrm{~B}$ & - \\
\hline
\end{tabular}

The applied biological products significantly reduced the concentration of nickel in spring wheat grain compared with untreated control. In their work, Jastrzębska and Kostrzewska (2019) pointed to the fact that phosphorus-dissolving Bacillus bacteria contributed to reduction in nickel content in spring wheat grain. Similarly, Sarfaz et al. (2019) and Figueiredo et al. (2011) reported that also rhizobacterine limits heavy metal content in plants. Plant growth promoting rhizobacteria (PGPR) are responsible for stimulating plant growth, heavy metal sequencing and break-down of toxic elements present in soil (Garcia-Fraile et al., 2015). A similar relationship was reported by Athar and Ahmad (2018) who examined Azotobacter. Naveed et al. (2020) and Turan et al. (2018) demonstrated that an application of bacteria contributed to a decline in the spring wheat grain content of nickel. In the present work, also an application of the amino acid L-alpha proline was followed by a decline in nickel content in spring wheat grain, particularly when combined with the bacteria Bacillus megaterium var. phosphaticum. It was confirmed by Popko et al. (2018) who demonstrated that an application of biostimulants contributes to a decline in the spring wheat content of nickel. In the study reported here, increasing rates of mineral fertilisation with nitrogen, in particular the rate $120 \mathrm{~kg} \mathrm{~N} \mathrm{Na}^{-1}$, were followed by an increase in nickel content in spring wheat grain. 
However, even in the case of the highest $\mathrm{N}$ rate, $\mathrm{Ni}$ content in spring wheat grain was low and did not exceed standards set by the WHO/FAO and was not harmful to humans (Adefarati et al., 2017). This finding was confirmed by Shicheng et al. (2018) in their research on an application of mineral fertilisation with NPK. In the experiment reported here, an interaction was found and it indicated that the lowest nickel content was present in spring wheat grain following an application of the bacteria Bacillus megaterium var. phosphaticumand the amino acid L-alpha proline and no mineral fertilisation with nitrogen, or an application of either 60 or $90 \mathrm{~kg} \mathrm{~N} \mathrm{ha}^{-1}$. By contrast, it was the highest for the untreated control where the rate of mineral fertilisation with nitrogen was either 90 or $120 \mathrm{~kg} \mathrm{Nha}^{-1}$.

Chromium content in spring wheat grain was significantly affected by the experimental factors and their interplay (Table 7).

Table 7. Chromium content in spring wheat grain (means across 2017-2019), $\mathrm{mg} \mathrm{kg}^{-1} \mathrm{DM}$

\begin{tabular}{c|c|c|c|c|c}
\hline \multirow{2}{*}{ Biological products (A) } & \multicolumn{2}{|c|}{ Mineral fertilisation with nitrogen, $\mathbf{k g ~ N}^{-\mathbf{1}} \mathbf{( B )}$} & \multirow{2}{*}{ Means } \\
\cline { 2 - 5 } & Control & $\mathbf{6 0}$ & $\mathbf{9 0}$ & $\mathbf{1 2 0}$ & \\
\hline Control & $0.314 \mathrm{~b}$ & $0.362 \mathrm{c}$ & $0.423 \mathrm{c}$ & $0.495 \mathrm{c}$ & $0.399 \mathrm{C}$ \\
$\begin{array}{c}\text { Bacillus megaterium var. } \\
\text { phosphaticum }\end{array}$ & $0.186 \mathrm{a}$ & $0.214 \mathrm{a}$ & $0.261 \mathrm{a}$ & $0.323 \mathrm{a}$ & $0.246 \mathrm{~A}$ \\
$\begin{array}{c}\text { L-alpha proline } \\
\text { Bacillus megaterium var. }\end{array}$ & $0.211 \mathrm{a}$ & $0.261 \mathrm{~b}$ & $0.317 \mathrm{~b}$ & $0.376 \mathrm{~b}$ & $0.291 \mathrm{~B}$ \\
phosphaticum + L-alpha proline & $0.158 \mathrm{a}$ & $0.185 \mathrm{a}$ & $0.223 \mathrm{a}$ & $0.272 \mathrm{a}$ & $0.210 \mathrm{~A}$ \\
\hline Means & $0.217 \mathrm{~A}$ & $0.256 \mathrm{~A}$ & $0.306 \mathrm{~B}$ & $0.367 \mathrm{C}$ & - \\
\hline
\end{tabular}

Biological products significantly reduced chromium content in spring wheat grain compared with untreated control. Also Jastrzębska and Kostrzewska (2019) reported that the phosphorus-dissolving bacteria Bacillus megaterium reduced chromium concentration in spring wheat grain. Sarfaz et al. (2019), Figueiredo et al. (2011) and Rizvi et al. (2020) demonstrated that bacteria incorporated into soil reduce chromium content in wheat. Also in the present study, an application of the amino acid L-alpha proline contributed to a decline in chromium content in spring wheat grain compared with control. Similarly, Popko et al. (2018) found that biostimulants reduce heavy metals in wheat. In the experiment reported here, the lowest chromium content was recorded in spring wheat grain following an application of the bacteria Bacillus megaterium var. phosphaticumand the amino acid L-alpha proline. Mineral fertilisation with nitrogen affected chromium content in spring wheat grain, too. The highest chromium content was determined in spring wheat grain following the highest rate of mineral fertilisation with nitrogen, that is $120 \mathrm{~kg} \mathrm{~N}^{-1}$. Despite this, the chromium content was low and did not exceed standards set by the WHO/FAO, and was safe for humans (Adefarati et al., 2017). Also research by Shicheng et al. (2018) demonstrated that mineral fertilisation is associated with an increase in the spring wheat grain content of chromium. An interaction was confirmed in the study reported here which indicated that the highest chromium content was present in spring wheat grain following an application of the bacteria Bacillus megaterium var. Phosphaticum and the amino acid L-alpha proline and no mineral fertilisation with nitrogen or at the rates of 60 or $90 \mathrm{~kg} \mathrm{~N}^{-1}$. 


\section{Conclusions}

1. Weather conditions during the growing season significantly affected heavy metal contents in spring wheat grain.

2. The examined biological products significantly reduced heavy metal contents in spring wheat grain, excluding zinc content.

3. Increasing rates of mineral fertilisation with nitrogen contributed to an increase in the spring wheat grain content of heavy metals. The only exception was zinc content determined in the grain of spring wheat fertilised with $120 \mathrm{~kg} \mathrm{~N}^{-1}$.

4. The lowest heavy metal contents were recorded in the grain of spring wheat treated with the bacteria Bacillus megaterium var. phosphaticum + the amino acid L-alpha proline, whether the cereal was unfertilised or fertilised with 60 and $90 \mathrm{~kg} \mathrm{~N}^{\circ} \mathrm{ha}^{-1}$.

5. Research on the use of bacillus bacteria and biostimulants in spring wheat cultivation should be continued and the content of heavy metals in the grain should be constantly monitored.

\section{REFERENCES}

[1] Adefarati, O., Adedeji, P. O., Ajala, O. (2017): Determination of heavy metal levels in green pea (Pisum sativum) a case study of selected markets in Abuja, FCT. - American Journal of Innovative Research and Applied Sciences. www.american-jiras.com.

[2] Asfa, R., Almas, Z., Fuad, A., Bilal, A., Muneera, D. F., AlKahtani, F., Saghir, K. (2020): Heavy metal induced stress on wheat: phytotoxicity and microbiological management. The Royal Society of Chemistry 10: 38379-38403.

[3] Athar, M. J., Ullah, S., Ahmad, I., Rauf, A., Nadeem, S. M., Khan, M. Y., Hussain, S., Bulgariu, L. (2018): Nickel phytoextraction through bacterial inoculation in Raphanus sativus. - Chemosphere 190: 234-242.

[4] Calvo, P., Nelson, L., Kloepper, J. W. (2014): Agricultural uses of plant biostimulants. Plant Soil 383: 3-41.

[5] Demirezen, D., Ahmet, A. (2006): Heavy metal levels in vegetables in Turkey are within safe limits for $\mathrm{Cu}, \mathrm{Zn}, \mathrm{Ni}$ and exceeded for $\mathrm{Cd}$ and $\mathrm{Pb}$. - Journal of Food Quality 29: 252265.

[6] Du Jardin, P. (2015): Plant biostimulants: definition, concept, main categories and regulation. - Sci. Hort. 196: 3-14.

[7] Figueiredo, M. V. B., Selin, L., Araujo, F. F., Mariano, R. L. R. (2011): Plant growth promoting rhizobacteria: fundamentals and applications. - In: Maheshwari, D. K. (ed.) Plant growth and health promoting bacteria. Berlin: Springer-verlag, pp. 21-42.

[8] Fytianos, K., Katsianis, G., Triantafyllou, P., Zachariadis, G. (2001): Accumulation of heavy metals in vegetables grown in an industrial area in relation to soil. - Bulletin of Environment Contamination and Toxicology 67: 423-430.

[9] Garcia-Fraile, P., Menendez, E., Rivas, R. (2015): Role of bacterial biofertilizers in agriculture and forestry. - AIMS Bioengineering 2: 183-205.

[10] Hellal, F. A., Zeweny, R. M., Yassen, A. A. (2012): Evaluation of nitrogen and silicon application for enhancing yield production and nutrient uptake by wheat in clay soil. - J. Ap. Sci. Res. 8: 686-692.

[11] Jamova, K., Valko, M. (2011): Advances in metal-induced oxidative stress and human disease. - Toxicol. 283: 65-87.

[12] Jastrzębska, M., Kostrzewska, M. K. (2019): Using an environment-friendly fertiliser form sewage sludge ash with the addition of Bacillus megaterium. - Minerals 9: 423. doi: $10.3390 / \min 9070423$. 
[13] Kandii, A. A., Sharief, A. E. M., Sedh, S. E., Altai, D. S. K. (2016): Role of humic acid and amino acids in limiting loss of nitrogen fertilizer and increasing productivity of some wheat cultivars grown under newly reclaimed sandy soil. - Int. J. Adv. Res. Biol. Sci. 394: 123-136.

[14] Khajeh, M., Moghaddam, A. R. A., Sanchooli, E. (2010): Application of Doehlert design in the optimization of microwave-assisted extraction for determination of zinc and copper in cereals samples using FAAS. - Food Anal methods 3: 133-137.

[15] Luo, Y. W., Xie, W. H., Jin, X. X., Wang, Q., He, Y. J. (2013): Effects of germination on iron, zinc, calcium, manganese, and copper availability from cereals. - CyTA-Journal of Food 12(1): 22-26.

[16] Mahamed, H. H., Kaharia, M. (2012): Assessment of some heavy metals in vegetables, cereals and fruits in Saudi Arabian markets. - Egyptian Journal of Aquatic Research 38: 31-37.

[17] Muchuwenti, M., Birkett, J. W., Chinyanga, E., Zvauya, R., Scimshaw, M. D., Lester, J. N. (2006): Heavy metal content of vegetables irrigated with mixtures of wastewater and sewage sludge in Zimbabwe: Implications for human health. - Agriculture, Ecosystems and Environment 112: 41-48.

[18] Naveed, M., Bukhari, S. S., Mustafa, A., Ditta, A., Almri, S., El-Esawi, M. A., Rafique, M., Ashraf, S. (2020): Mitigation of nickel toxicity and growth promotion in sesame through the application of a bacterial endophyte and zeolite in nickel contaminated soil. International Journal of Environmental Research and Public Health 17: 8859. doi:10.3390/ijerph17238859.

[19] Ociepa-Kubicka, A., Ociepa, E. (2012): Toxic effect of heavy metals on plants, animals and animals, Engineering and Environment 15(2): 169-180.

[20] Pirsaheb, M., Fattahi, N., Sharafi, K., Khamotian, R., Atafar, Z. (2015): Essential and toxic heavy metals in cereals and agricultural products marketed in Kermanshah, Iran, and human health risk assessment. - Food Additives and Contaminants Part B. doi: 10.1080/19393210.2015.1099570.

[21] Popko, M., Michalak, I., Wilk, R., Gramza, M., Chojnacka, K., Górecki, H. (2018): Effect on the new plant growth biostimulants based on amino acids on yield and grain quality of winter wheat. - Molecules 23: 470. doi:10.3390/molecules23020470.

[22] Radkowski, A., Radkowska, I., Bocianowski, J., Florkiewicz, A. (2020a): Synergistic effects of foliar application of amino acid and silicon on the content of micro- and macroelements in phytomass of grassland. - J. Elem. 25(3): 879-891.

[23] Radkowski, A., Radkowska, I., Bocianowski, J. (2020b): Effect of the fertilization of meadow sward with amino acids obtained from enzymatic hydrolysis on silage quality. J. Elem. 25(1): 259-277.

[24] Rizvi, A., Zaidi, A., Ameen, F., Ahmed, B., AlKahtani, M. D. F., Khan, M. S. (2020): Heavy metal induced stress on wheat: phytotoxicity and microbiological management. Royal Society of Chemistry 10: 38379-38403.

[25] Sarfaz, R., Hussain, A., Sabir, A., Ibtissem, B. F., Allah, D., Shihe, X. (2019): Role of biochar and plant growth promoting rhizobacteria to enhance soil carbon sequestration. Environ. Monit. Assess. 191: 251. doi.org/10.1007/s10661-019-7400-9.

[26] Sharma, O. P., Bangar, K. S., Jain, R., Sharma, P. K. (2004): Heavy metals accumulation in soil irrigated by municipal and industrial effluent. - Journal of Environmental Science and Engineering 46(1): 65-73.

[27] Shicheng, Z., Shaoju, Q., Ping, H. (2018): Changes of heavy metals in soil and wheat grain under long-term environmental impact and fertilization practices in North China. - Journal of plant Nutrition 41(3): 1-10.

[28] Srinivas, N., Vinod Kumar, B., Suresh Kumar, K. (2002): Lead pollution in roadside plant in Visakhapatinam. - Journal of Environmental Studies and Pol. 5(1): 63-68.

[29] Thielecke, F., Nugent, A. P. (2018): Contaminants in Grain - A Major Risk for Whole Grain Safety? - Nutrients 10(9): 1213. 
[30] Turan, V., Khan, S. A., Mahmood-ur-Rahman, Iqbal, M., Ramzani, P. M. A., Fatima, M. (2018): Promoting the productivity and quality of brinjal aligned with heavy metals immobilization in a wastewater irrigated heavy metal polluted soil with biochar and chitosan. - Ecotoxicol. Environ. Saf. 161: 409-419.

[31] Vejan, P., Abbullah, R., Khadiran, T., Ismail, S., Nasrulhaq, B. (2016): Role of plant growth promoting rhizobacteria in agricultural sustainability. - Molecules 12(5): 1-17.

[32] WHO. (2001): Food additives and contaminants. - Joint Codex Alimentarius Commission, FAO/WHO Food standards Programme, 2001; ALINORM 01/12A.

[33] Zakir, H., Brennan, J. D. (2011): $\beta$-galactosidase-based colorimetric paper sensor for determination of heavy metal. - Anal. Chem. 83: 772-8778.

[34] Zheng, Y., Li, X-K., Wang, Y., Cai, L. (2008): The role of zinc, copper and iron in the pathogenesis of diabetes and diabetic complications: therapeutic effects by chelators. Hemoglobin 32: 135-145. 